DOI: 10.14526/2070-4798-2019-14-2-43-47

\title{
Effectiveness of complex lessons with swimming and hatha yoga predominance influence on psychophysical state of 21-35 year-old men
}

\author{
Ilona V. Adamova \\ Russian State University of Physical Culture, Sport, Youth and Tourism \\ Moscow, Russia \\ ORCID: oooo-ooo2-5370-3771, Ilona-adamova@rambler.ru
}

\begin{abstract}
The problem of physical state among middle age people of the 1st period, as the most socially significant age group, is interesting for the specialists in the sphere of physical culture and sport. It should be noted that in spite of great practical experience in this sphere, there is no sufficient theoretical substantiation of the effective swimming and hatha yoga programs integration for middle age people of the 1st period. Materials. This article presents the methodology of complex swimming and hatha yoga lessons and this methodology influence. Research methods. Information sources analysis and summarizing, questionnaire survey and interview, pedagogical experiment, social-psychological research with two methodologies use (the level of functional and psycho-emotional state revelation with the help of HAM map (on the basis of a subjective estimation) according to each parameter: "Health", "Activity" and "Mood" and according to a simplified variant of Lüscher test "Short test", which helps to analyze psycho-emotional state thoroughly), methods of mathematical statistics. Results. The results of the pedagogical experiment showed that complex swimming and hatha yoga lessons have expressed health-improving orientation. We revealed the effectiveness of complex swimming and hatha yoga lessons influence on the indices. They characterize the middle age people psychoemotional state level. The created complex methodology with swimming and hatha yoga means use can be recommended for physical culture lessons among middle age people of the first period and in order to provide safety during swimming lessons and swimming skills improvement among middle age people. Conclusion. The received research results concerning the complex methodology (using swimming and hatha yoga means) influence on psycho-emotional state of those, who train can be used during the "theory and methodology of physical-health improving activity" profile and in practical activity of instructors-methodists, people, who work at physicalhealth-improving establishments and personal coaches.

Keywords: physical culture and health improving technologies, complex lessons, swimming, hatha yoga, the first period of middle age.
\end{abstract}

For citation: Ilona V. Adamova*. Effectiveness of complex lessons with swimming and hatha yoga predominance influence on psychophysical state of 21-35 year-old men. The Russian Journal of Physical Education and Sport. 2019; 14(2): 38-41. DOI 10.14526/2070-4798-2019-14-2-43-47

\section{Introduction}

Modern life conditions of living in a megalopolis with the increasing scientific-technical stream of information lead to a person's psychic and physical over-tension $[5,6,7]$.

An effective means of physical activity increase, locomotor apparatus, pectoral sling strengthening, cardiovascular, respiratory and other systems of an organism improvement is a complex system of physical exercises use. It includes the combination of swimming and different healthimproving methodologies [2,3,8]: aquaaerobics or hydroaerobics, hydroshaping [2,5,6]; pilates and swimming, stretching and swimming $[1,4,10]$, yoga and swimming [9,12].

In yoga and swimming people achieve the state of deep relaxation. Combined approach use during health-improving programs realization increases the effectiveness of lessons owing to monotony level decrease, a wider spectrum of physical exercises mastering, psycho-physiological mechanisms of positive emotions inclusion $[7,8,11]$.

The aim of the research is to create and experimentally substantiate the methodology of complex lessons with swimming and hatha yoga means predominance for middle age people of the 1st period.

The objectives of the research: 
1. To define the initial level of middle age men of the 1st period psycho-emotional state.

2. To create the methodology of complex lessons with swimming and hatha yoga mean predominance.

3. To reveal the effectiveness of complex lessons influence with swimming and hatha yoga means predominance on the indices. They characterize the level of psycho-emotional state among the men of the 1st period of middle age.

\section{Materials and methods}

Information sources analysis and summarizing, questionnaire survey and interview, pedagogical experiment, social-psychological research with two methodologies use (the level of functional and psycho-emotional state revelation with the help of HAM map (on the basis of a subjective estimation) according to each parameter: "Health", "Activity" and "Mood" and according to a simplified variant of Lüscher test "Short test". It helps to analyze psycho-emotional state thoroughly), methods of mathematical statistics.

\section{Results and Discussion}

14 men (23-32 years-old) took part in the pedagogical experiment. The leading motives of attending complex lessons, which include yoga and swimming, were the desire to strengthen muscles and to lose weight, improve health state and mood. The lessons were organized 3 times a week: 2 times a week- an hour and a half of swimming (exercises for breathing from yoga, preparatory exercises for swimming, articulate warming up - 30 minutes, distance swimming-6o minutes), once a week-yoga (an hour and a half).

This methodology is directed toward swimming skills development among people, who can't swim or for people, who can swim, but don't know correct technique. The lessons are directed toward acquaintance with water (for those, who can't swim), getting rid of stress by means of relaxation, teaching breathing into water, teaching basic exercises in water, teaching all styles of swimming, teaching exercises from yoga, teaching respiratory exercises, teaching articulate warming up. According to the results of a questioner survey and a medical checkup all respondents were included into the main and preparatory medical groups and didn't have contraindication to swimming and hatha yoga. It was revealed that $83 \%$ of the respondents go in for mental work and $17 \%$ go in for other kinds of labor.

The ratio of respondents according to the type of activity is presented in picture 1 .

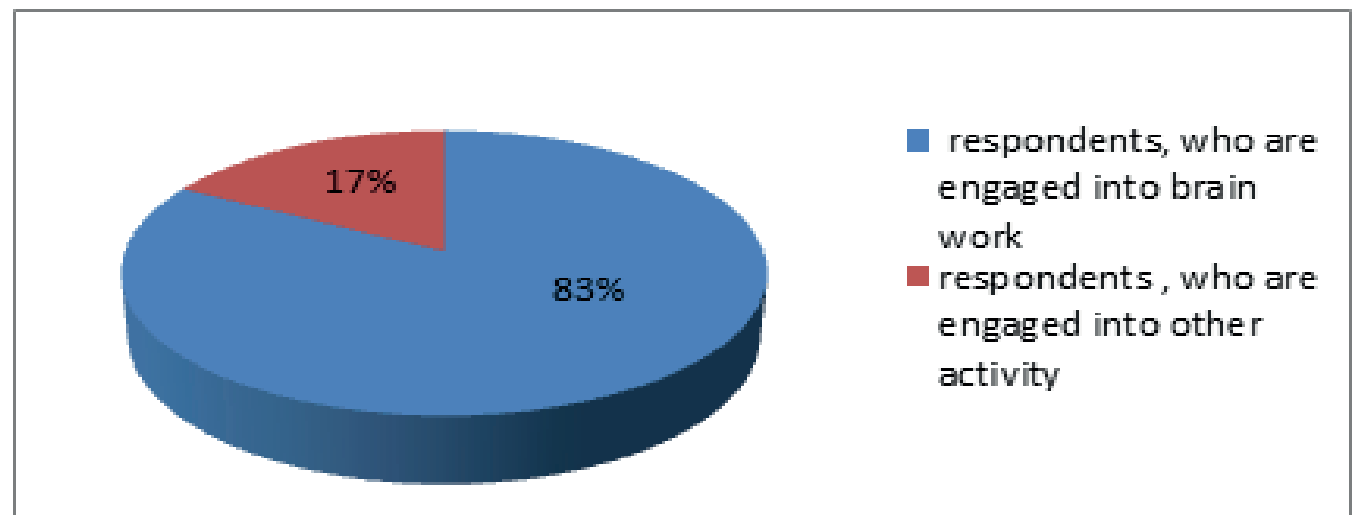

Picture 1 - The ratio of respondents according to the type of activity

We revealed the effectiveness of complex lessons influence, with swimming and hatha yoga means predominance, on the indices, which characterize the level of functional state according to HAM map (on the basis of a subjective estimation) according to each parameter: "Health", "Activity" and "Mood" and according to a simplified variant of Lüscher test "Short test" among the men of the 1st period of the middle age.

Thus, on the basis of the results analysis, received after HAM test and table 1 results handling, we define the following indices improvement: health state for 5 points, activity index for 1,16 units, mood for 1,34 units. Statistical validity of shifts estimation in the group before and after the pedagogical experiment was demonstrated according to Wilcoxon Matched 
Pairs Test for the level of validity $\mathrm{p} \leq 0,05$.

Table 1 - The dynamics of functional and psycho-emotional state indices among men $(n=14)$

\begin{tabular}{|c|c|c|c|}
\hline Indices & $\begin{array}{c}\mathrm{X} \text { av }+\mathrm{m} \\
\text { before the experiment, }\end{array}$ & $\begin{array}{c}\mathrm{X} \text { av }+\mathrm{m} \\
\text { after the experiment, }\end{array}$ & $\mathrm{P}$ - level \\
\hline Health & $39,33+8,93$ & $44,33+6,57^{*}$ & 0,018365 \\
\hline Activity & $42,17+7,42$ & $43,33+7,18^{*}$ & 0,045361 \\
\hline Mood & $43,83+5,51$ & $45,17+5,34$ & 0,059745 \\
\hline Ind. $=\mathrm{M} /(\mathrm{H}+\mathrm{A})$ & $0,54+0,04$ & $0,52+0,06$ & 0,083746 \\
\hline $\begin{array}{c}\text { CV (coefficient of } \\
\text { vegetative tonus) }\end{array}$ & $0,88+0,16$ & $1,05+0,18^{*}$ & 0,001324 \\
\hline * $\leq 0,05 * * *$ P $\leq 0,001$
\end{tabular}

The results of Lüscher tests handling show index number increase of the vegetative tonus coefficient (CV). During the experiment CV increased for 0,17 units $(\mathrm{p}<0.05)$. It proves positive influence of a complex methodology, which combines swimming and yoga.

\section{CONCLUSION}

The created methodology of complex lessons, using swimming and hatha yoga means for the people of the first period of middle age, is presented as an educating, health-improving system. This methodology is directed toward swimming skills development among people, who can't swim or who can swim, but don't know correct technique. The lessons are directed toward acquaintance with water (for those, who can't swim), getting rid of stress by means of relaxation, teaching breathing into water, teaching basic exercises in water, teaching all styles of swimming, teaching exercises from yoga, teaching respiratory exercises. The result of this methodology introduction into practice is a positive dynamics of some psycho-emotional state indices among those, who train.

\section{REFERENCES}

1. Adamova I.V. Technology of complex lessons of health-improving kinds of gymnastics and swimming with 35-45 year-old women. Candidate's thesis. Moscow: Russian State Academy of Physical Culture. 2000: 19.

2. Voronchikhina I.A., Menkhi Y.V. Typology of health-improving process among middle age people during water aerobics lessons. Teoriya i praktika fizicheskoi kultury $=$ Theory and practice of physical culture. 2006; 4: 43 (In Russ., In Engl.).

3. Galeeva O.B., Yakovleva O.V. The effectiveness of a complex step-aerobics and hydroaerobics program estimation. Teoriya i praktika fizicheskoi kultury $=$ Theory and practice of physical culture. 2006; 1: 40 (In Russ., In Engl.).

4. Stepan A. Goniyants, Ilona V. Adamova, Vladimir A. Rvachev. Respiratory technologies in professional-applied physical culture among electric train drivers in the aspect of adaptation to psycho-emotional loads of professional activity. Pedagogiko-psihologicheskie I medicobiologicheskie problemy fizicheskoj kul'tury I sporta = Pedagogico-psychological problems of physical culture and sports. 2017; 12(1): 33-35. DOI: 10.14526/01_2017_181 (In Russ., In Engl.).

5. Zoz V.O., Adamova I.V. Methodical peculiarities of complex lessons with swimming and hatha yoga predominance with the people of the 1st period of the middle age. Nauka, Fitnes, Rekreatsiya - 2017. Materialy Vserossijskoj konferencii s mezhdunarodnym uchastiem. Moskva, Aprel' 6-7, 2017 [Science, Fitness, Recreation. Materials of All-Russian conference with the International participation. Moscow, April, 6-7, 2017]. Moscow: FSBEE HPE Russian State University of Physical Culture, Sport, Youth and Tourism. 2017: 78-84.

6. Evgeniya A. Raspopova, Yuliya A. Postolnik. Physical readiness increase among female students on the basis of innovative approach use to teaching swimming in terms of Physical culture discipline at a pedagogical higher educational establishment. Pedagogiko-psihologicheskie I medico-biologicheskie problemy fizicheskoj kul'tury I sporta $=$ Pedagogico-psychological problems of 
physical culture and sports. 2018; 13(4): 62-66. DOI: $\quad 10.14526 / 2070-4798-2018-13-4-73-79$ (In Russ., In Engl.).

7. Cider A., Schaufelberger M., Sunnerhagen K.S., Andersson B. Hydrotheropy - a new approach to improve function in the older patient with chronic heart failure. The European Journal of Heart Failure. 2003; 5: 527-535.

8. Daley M.J., Spinks W.L. Exercise, mobility and aging. Sports Medicine. 2000; 1: 1-12.

9. Fiatarone M. Benefits of exercise and dietary measures to optimize shifts in body composition with age. The American Journal of Clinical Nutrition. 2002; 11: 642-652.

10. Lauretani F., Russo C.R., Bandinelli S., Bartali B., Cavazzini C., Di Iorio A., et al. Age- associated changes in skeletal muscles and their effect on mobility: An operational diagnosis of sarcopenia. Journal of Applied Physiology. 2003; 95: 1851-1860.

11. Pollok M.L., Gaesser G.A., Butcher J.D., Despres J.-P., Dishman R.K., Franklin B.A., et al. The recommended quantity and quality of exercise for developing and maintaining cardiorespiratory and muscular fitness and flexibility in healthy adults. Medicine and Science in Sports and Exercise. 1998; 30(6): 975-992.

12. Volaklis K.A., Spassis A.T., Tokmakidis S.P., Greece K. Land versus water exercise in patients with coronary artery disease: Effects on body composition, blood lipids and physical fitness. American Heart Journal. 2007; 154: 560.e1-560.e6.

Submitted: 07.04.2019

\section{Author's information:}

Ilona V. Adamova - Candidate of Pedagogics, Associate Professor, Russian State University of Physical Culture, Sport, Youth and Tourism, 105122, Russia, Moscow, Sirenevyj bulvar, House 4, e-mail: Ilona-adamova@rambler.ru 